\title{
Growth of the hatchery-produced juveniles of commercial sea cucumber Holothuria (Theelothuria) spinifera Theel
}

\author{
P S Asha \& P Muthiah \\ Tuticorin Research Centre of Central Marine Fisheries Research Institute,Tuticorin,Tamil Nadu, India
}

Correspondence: P S Asha, Tuticorin Research Centre of Central Marine Fisheries Research Institute, South Beach Road Extension, Tuticorin 628 001,Tamil Nadu, India. E-mail: ashasanil@yahoo.com

\begin{abstract}
The present study was conducted to develop the hatchery technology for seed production of the widely exploited commercial sea cucumber Holothuria spinifera Theel 1886, to facilitate an effective stock enhancement programme. Broodstock collected by skin divers were used for spawning trials. The embryonic and larval stages were similar to other aspidochirotes. The larval survival rate was $43.5 \%$ on day 9 , which decreased to $18.3 \%$ nearing metamorphosis on day 13, the growth rate was $48 \mu \mathrm{m}_{\text {day }}{ }^{-1}$ and the settlement rate was $3.5 \%$. Alga-

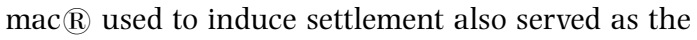
food source for the early settled juveniles, followed by Sargassum spp. extract $(<40 \mu \mathrm{m})$ for the first month. Sargassum spp. powder along with fine sand (1:1) was given to juveniles $>20 \mathrm{~mm}$. Addition of Spirulina spp. along with Sargassum spp. powder and fine sand (0.5:1:2) enhanced the growth rate of the juveniles. In the hatchery, the juveniles attained an average size of 1,30 and 48 on 20,80 and 120 days respectively.
\end{abstract}

Keywords: Holothuria spinifera, survival rate, Algamac $($ R, Sargassum spp., Spirulina spp.

\section{Introduction}

Sea cucumbers belonging to the families Holothuridae and Stichopodidae form an important part of multispecies fishery, existing for over 1000 years along the Indo-Pacific region, and the processed product is a valuable source of income. Increasing demand and inadequate management of sea cucumber stocks in many countries have resulted in severe overexploitation of commercially important species. Bruckner, Johnson and Field (2003) reported that the holothurians are susceptible to overexploitation because of late maturity, density-dependent reproduction and low rate of recruitment. The release of hatchery-produced juvenile sea cucumbers into the natural habitat is being advocated in many countries as one of the means of rebuilding the wild stock, a process termed as restoration, restocking or reseeding (Battaglene 1999).

The breeding and cultivation of holothurians dates back to 1950, with the first recorded production of juveniles of Stichopus japonicus (Imai, Inaba, Sato \& Hatanaka 1950). Later, studies on reproduction, early development and metamorphosis of Cucumaria elongata (Chia \& Buchanan 1969), C. pseudocurata (Rutherford 1973), Aslia lefevrai (Costelloe 1988), Psolus chitonoides and P. bullatum (McEuen \& Chia 1991) and C. frondsa (Hamel \& Mercier 1996) were extensively undertaken. Meanwhile in 1985, techniques were developed for producing juveniles of S. japonicus in China (Shuxu \& Gongchao 1981; Chen 2003) and seed of Actinopyga echinites in Taiwan (Chen \& Chian 1990).

Following the Chinese method, James, Rajapandian, Baskar and Gopinathan (1988) successfully produced the seed of Holothuria scabra for the first time. This technique was later applied for the seed production of sea cucumbers in Australia, Indonesia, Maldives and Solomon Islands (Battaglene 1999). The seeds of Isostichopus fluscus and H. fuscogliva have been successfully produced in Ecuador and in Kirbati Island (Hamel, Hidalgo \& Mercier 2003; Friedman \& Tekanene 2005). 
In India, the beche de-mer industry mainly depends on two species, H. scabra and H. spinifera (Chellaram, Samuel \& Patterson Edward 2003), and both the species are being processed for export. Holothuria spinifera, locally called cheena attai or raja attai, was once rated very high in the market and was in good demand in China. At present, the market value is moderate; the processed ones $\left(60\right.$ counts $\mathrm{kg}^{-1}$ ) fetch US \$37.5. Besides Gulf of Mannar and Palk Bay of Indian coast, this species is reported to occur in the Red sea, Persian Gulf, Sri Lanka, North Australia, Philippines and China (James 1995). James and Badrudeen (1997) reported an estimated annual landing of 460 tonnes of fresh $H$. spinifera along the south-east coast of India. Increase in demand and inadequate fishery management has resulted in overexploitation of commercial sea cucumber species in India also; hence, the Ministry of Environment, Government of India, has banned both fishery and export of sea cucumbers since 2001, which has had a severe impact on the livelihood of poor coastal communities subsisting on its fishery and processing. Owing to the role played by $H$. spinifera in the commercial fishery and also due to its indiscriminate exploitation, knowledge of early development, larval and juvenile rearing is essential for the seed production so as to carry out, the captive or wild stock enhancement programme of this species effectively. Hence, an attempt was made to produce juveniles of $H$. spinifera in the laboratory. The present work is the first successful attempt of juvenile production of this species under laboratory conditions.

\section{Materials and methods}

The broodstock of $H$. spinifera collected by skin divers were maintained in $1000 \mathrm{~L}$ FRP tanks having $150 \mathrm{~mm}$ thickness of fine coral beach sand at the bottom. The water was exchanged daily and sand every fortnight and the brooders were fed with Sargassum spp. powder at the rate of $5 \%$ of their body weight.

For induced spawning, among the 30 numbers of broodstock, 10 numbers were subjected to thermal stimulation wherein the holothurians were exposed to $3-4{ }^{\circ} \mathrm{C}$ above the ambient temperature for an hour. The high temperature was maintained by a heating element controlled by a thermostat. Similarly, inducement by addition of feed constituted by rice bran, Soya powder and Sargassum spp. powder (4:1:2) at a

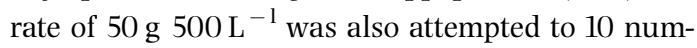
bers and the remaining 10 numbers were maintained as control.
For holothurian seed production 150000 fertilized eggs, 5700 pentactulae and 2000 juveniles were reared in a lot following the hatchery technique (James et al. 1988; Battaglene 1999; Chen 2003).While rearing, periodically representative samples were measured for assessing the growth of larvae and juveniles. The microalgae cultured by the serial dilution technique (Gopinathan 1982) were provided as larval feed as indicated in Asha and Muthiah (2006) and at a concentration specified by Asha (2004).

The doliolaria larvae on 10th day were maintained in a flowthrough system, in which an equal volume of seawater released was let in and were provided with Algamac $\AA$ (Bio-Marine, Hawthrone, CA, USA) at a

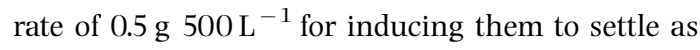
pentactulae. The Algamac $\AA$ was provided for 13 days until the juveniles became visible to the naked eye.

For the newly settled juveniles, Sargassum spp. extracts $(<40 \mu \mathrm{m})$ were given $\left(10 \mathrm{~L} 500 \mathrm{~L}^{-1}\right)$ for 4 weeks. When the juveniles attained an average length of $20 \mathrm{~mm}$, a mixture of Sargassum spp. powder and fine sand in a proportion of (1:2) was given at $1 \%$ of the body weight of juveniles (initially $<80$; $<200 \mu \mathrm{m}$ as the days progressed). From day 30, Spirulina spp. (15 mg juvenile ${ }^{-1}$ ) was provided along with the above feed. Every week, juveniles were taken out using a fine brush and the length and number of live juveniles were noted for assessing the growth and survival rate. Once in a week, the juveniles were transferred to another tank as suggested by Battaglene (1999). The juveniles thus produced from fertilized eggs were reared up to 120 days.

\section{Results and discussion}

\section{Spawning and development}

The induced spawning on 2 January 2003 occurred in the afternoon, after addition of feed. There was no spawning by thermal stimulation. The female spawned first, followed by three males.

The spawning in H. spinifera was induced by addition of feed. Addition of Algamac( $\mathrm{R}$ at $50 \mathrm{~g} 500 \mathrm{~L}^{-1}$ induced spawning in H. fuscogilva (Battaglene, Seymour \& Ramofafia 2002). Thermal stress, despite having been effective for S. japonicus (Ishida 1979), H. scabra (James et al. 1988) and H. scabra and A. mauritiana (Battaglene et al. 2002), did not induce H. spinifera to spawn. Similarly, Battaglene et al. (2002) observed that thermal stress was not effective but addition of dried algae alone yielded induced spawning in H. fuscogilva. 
In the successful spawning experiment, the females spawned first, followed by the males. Because the released gonadal materials instigate the mass spawning, the blended gonad from mature broodstock may be an effective spawning stimulant (Battaglene 1999).

The spawning behaviour of $H$. spinifera and the occurrence of spawning in the afternoon were similar to the observations on other aspidochirotids (McEuen 1988). The spawning in the late afternoon and evening may be related to a decrease in light intensity as opined by McEuen (1988). Fertilization and early embryonic development and other larval stages of $H$. spinifera are similar to those of other aspidochirote holothurians (Ishida 1979; Maruyama 1980; Chen \& Chian 1990).

\section{Larval and juvenile rearing}

The chronological developmental stages and the details of the various larval stages up to pentactulae with the time of occurrence and the mean size were as described by Asha and Muthiah (2002).

The doliolaria stage was attained on day 10 in $H$. spinifera, which was similar in H. scabra (James et al. 1988; Battaglene, Seymour \& Ramofafia 1999). It took 15 days at $25-28^{\circ} \mathrm{C}$ to reach doliolaria in A. echinites (Chen \& Chian 1990). During the rearing period of the larvae and juveniles, the seawater temperature ranged from 29 to $31^{\circ} \mathrm{C}$, salinity from 34.8 to $36 \mathrm{ppt}$, $\mathrm{pH}$ from 8.1 to 8.2 and dissolved oxygen from 4.1 to $5.2 \mathrm{~mL}^{-1}$. The attainment of doliolaria on day 10 for H. spinifera may be due to the larval rearing at a higher temperature of $29-31{ }^{\circ} \mathrm{C}$. Asha and Muthiah (2005) indicated, a water temperature of $28-32{ }^{\circ} \mathrm{C}$ as the optimum for rearing the larvae of $H$. spinifera.

During the spawning trial, $43.8 \%$ of auricularia were hatched out from 1500000 fertilized eggs. On day 3 , the survival rate was $79.9 \%$, which decreased to $63.9 \%$ and $43.5 \%$ on days 5 and 9 respectively. On day 11 , the survival was $39.6 \%$. Nearing metamorphosis, on day 13 , the survival rate was $18.3 \%$.

The larval growth rate was $48 \mu \mathrm{m}_{\text {day }}{ }^{-1}$ and the growth equation indicated a high level of significance $(r=0.9695 ; P<0.01)$ (Fig. 1$)$.

The metamorphosis and settlement are the critical stages in the development of sea cucumber larvae (Preston 1993). In this study, Algamac $\AA$ was used as the settlement cue. Battaglene (1999) also observed high settlement using Algamac( in H. scabra. In H. spinifera, Asha and Muthiah (2002) reported more settlement $(40 \%)$ of Algamac $($-fed larvae, followed by $20 \%$ for periphytic diatom-fed larvae. Ito and Kitamura (1997) accelerated the metamorphosis in $S$. japonicus by providing periphytic diatom at $>20000$ cells $\mathrm{cm}^{-2}$. Studies have to be undertaken to evolve suitable cues and their concentration so as to obtain more juveniles.

On day 15, 5700 pentactulae of $0.32 \mathrm{~mm}$ length, forming $9.4 \%$ of early auricularia, were produced. On day 23, 2000 juveniles of $0.95 \mathrm{~mm}$, forming 3.5\% of early auricularia, were reared. On day 31 , the juveniles had a mean length of $2.3 \mathrm{~mm}$ (Fig. 2a) and the survival rate was $7.5 \%$. On day 48 , the length of the juveniles ranged from 6 to $14 \mathrm{~mm}$, with a mean of $10.1 \mathrm{~mm}$ (Fig. 2b) and the survival rate was 3.5\% (Fig. 3). Adding Spirulina spp. along with Sargassum spp., a growth rate of $1.5 \mathrm{~mm} \mathrm{day}^{-1}$ was obtained. On day 85, 56 juveniles produced in the size range of 31-60 mm with a mean of $41 \mathrm{~mm}$ (Fig. 2c) were produced. The observed growth rate was $0.64 \mathrm{~mm}_{\text {day }}{ }^{-1}$ with a $2.8 \%$ survival. In the fourth month, the juveniles attained a mean size and weight of $48 \mathrm{~mm}$ and 2.84 g respectively (Fig. 2 d).

The growth of the juveniles can be described by the following equation:

$$
Y=0.0001 x^{2.8513}
$$

An $r=0.993$ indicated a high level $(P<0.01)$ of significance (Fig. 4).

During the juvenile rearing, maximum mortality (92.5\%) occurred on day 31 at $2.3 \mathrm{~mm}$ length. Battaglene et al. (1999) observed that juveniles of $<5 \mathrm{~mm}$ holothurians are more susceptible. The juveniles attained an average size of $41 \mathrm{~mm}(2.3 \mathrm{gm})$ on day 85 , with an average growth rate of $0.64 \mathrm{~mm}$ day $^{-1}$.

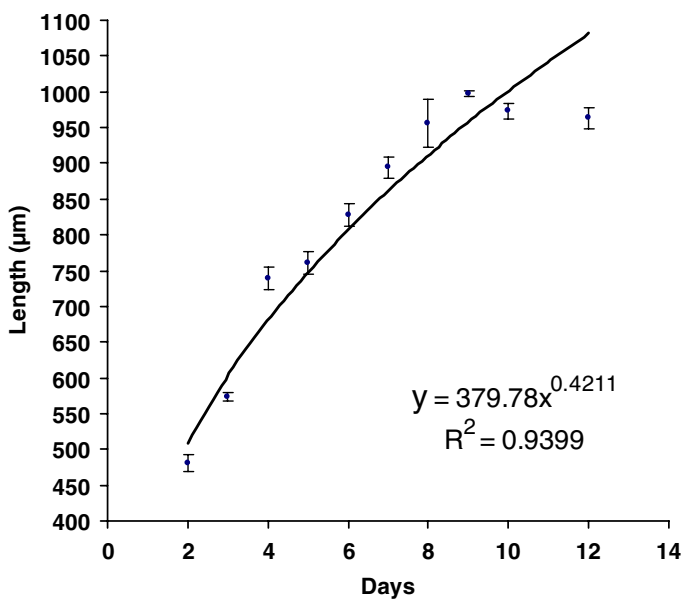

Figure 1 Growth rate of the larvae of Holothuria spinifera. 

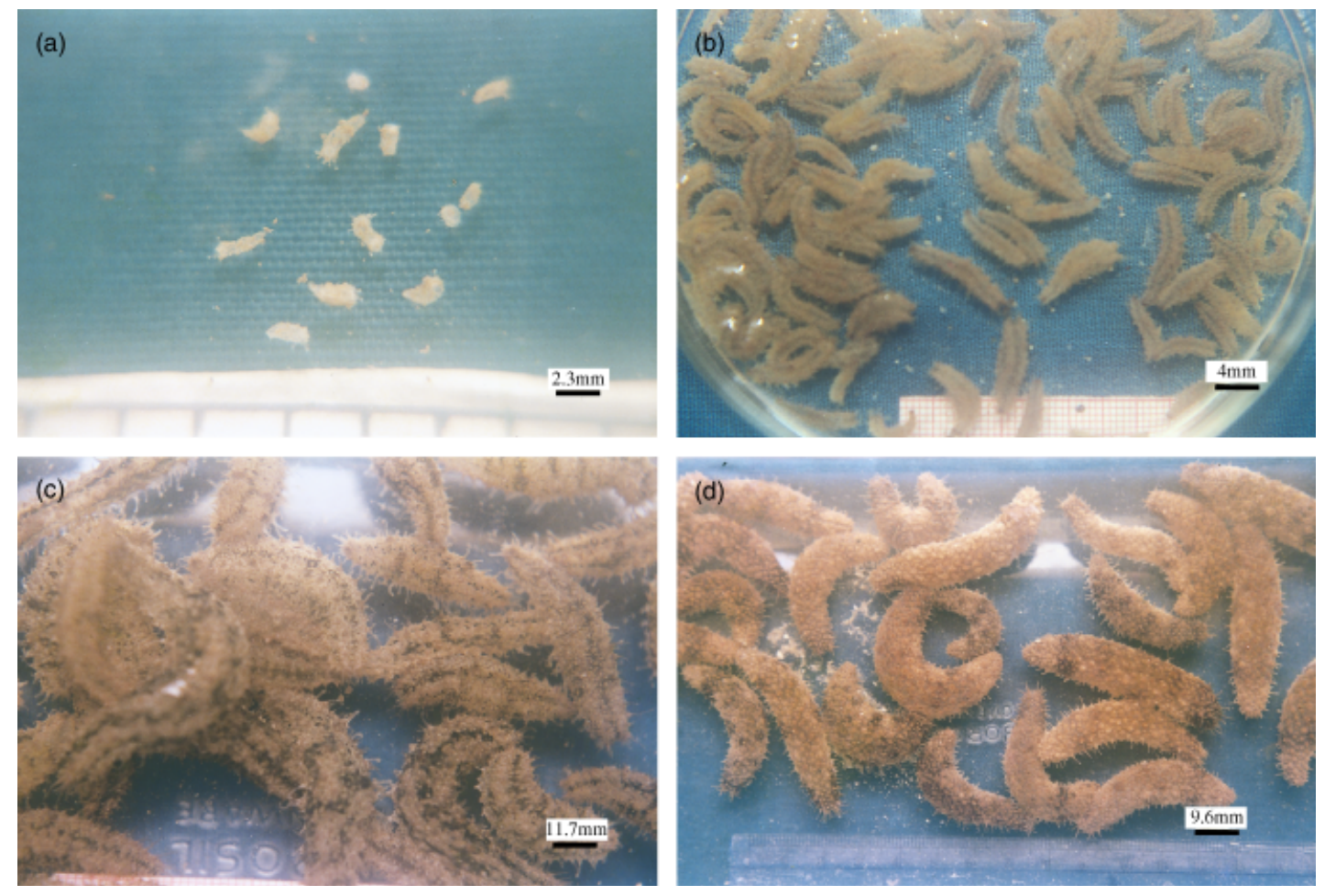

Figure 2 Juveniles of Holothuria spinifera (a) 31 days old, (b) 48 days old, (c) 85 days old, (d) 120 days old.

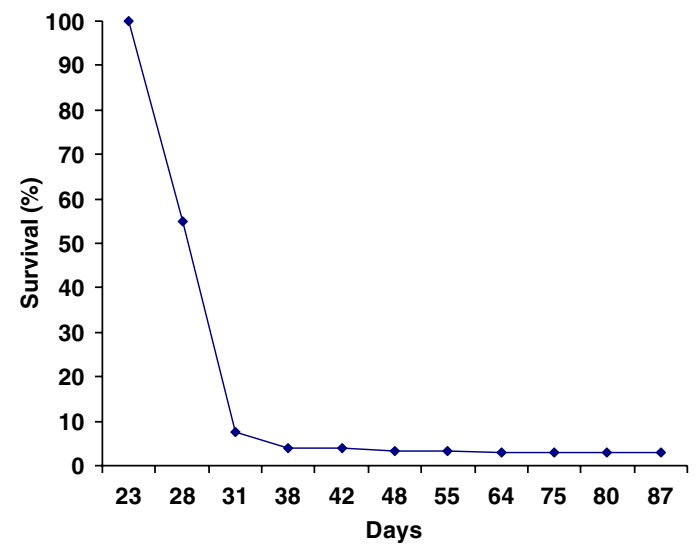

Figure 3 Survival rate of the juveniles of Holothuria spinifera.

Battaglene et al. (1999) recorded a $0.5 \mathrm{~mm}$ growth rate for $H$. scabra. The growth rate of $H$. spinifera was 10-20 mm greater in 3 months and was similar to $I$. japonicus (Ito \& Kitamura 1998). The average size of the juveniles sea ranched reported was $20-30 \mathrm{~mm}$ by James, Gandhi, Palaniswamy and Rodrigo (1994); $<60 \mathrm{~mm}$ and $20 \mathrm{~g}$ by Battaglene (1999); and $35 \mathrm{~mm}$ by Hamel et al. (2003). The juveniles of $H$. spinifera (mean length and weight $48 \mathrm{~mm}$ and $2.84 \mathrm{~g}$ ) pro-

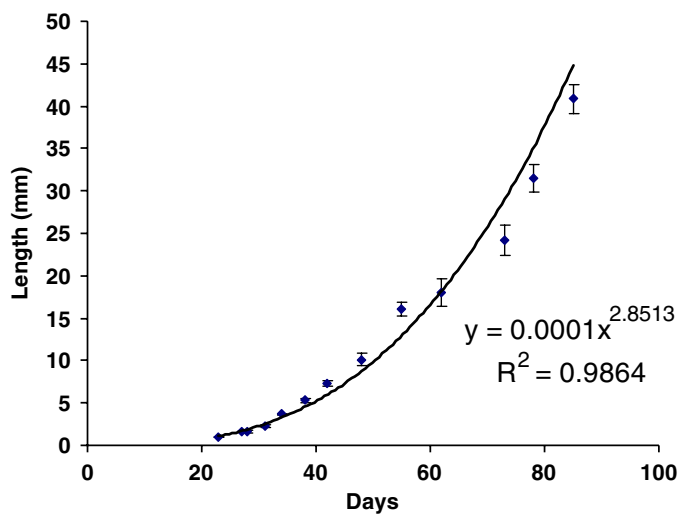

Figure 4 Growth rate of the juveniles of Holothuria spinifera.

duced in this study, after 120 days of growth in the hatchery, were sea ranched into the sea grass beds of Van Island area in Gulf of Mannar at $10 \mathrm{~m}$ depth for the first time. In this study, addition of Spirulina spp. increased the growth rate to $1.4 \mathrm{~mm}_{\text {day }}{ }^{-1}$ and it indicated that the probable role of additional protein source in the growth of juveniles and powdered algae is not a major source of food for juveniles (Battaglene et al. 1999). The feeding habit of the juvenile sea 
cucumber in the wild is unknown (Battaglene et al. 1999). Moreover, Yingst (1978) opined that many deposit-feeding holothurians do not appear to assimilate algae and have little cellulose activity in their gut. Hence, formulation of a suitable balanced diet for juveniles of sea cucumbers has to be given more thrust in future studies.

\section{Acknowledgments}

The authors express their sincere gratitude to Prof. (Dr) Mohan Joseph Modayil (Director) and Dr M. Rajagopalan (Head of Fishery Environment and Management Division) of CMFRI, Kochi, for their interest and encouragement.

\section{References}

Asha P.S. (2004) Effect of feed concentration on larval growth, survival and development of Holothuria (Theelothuria) spinifera Theel. Journal of Marine Biological Association of India 46, 80-86.

Asha P.S. \& Muthiah P. (2002) Spawning and larval rearing of the sea cucumber Holothuria (Theelothuria) spinifera Theel. SPC Beche-de-mer Information Bulletin 16, 11-15.

Asha P.S. \& Muthiah P. (2005) Effect of temperature, salinity and $\mathrm{pH}$ on the larval growth, survival and development of the sea cucumber Holothuria (Theelothuria) spinifera Theel. Aquaculture 250, 823-829.

Asha P.S. \& Muthiah P. (2006) Effect of single and combined microalgae on larval growth, survival and development of commercial sea cucumber Holothuria spinifera Theel. Aquaculture Research 37, 113-118.

Battaglene S.C. (1999) Culture of tropical sea cucumbers for stock restoration and enhancement. Naga 22, 4-10.

Battaglene S.C., Seymour J.E. \& Ramofafia C. (1999) Survival and growth of cultured sea cucumbers, Holothuria scabra. Aquaculture 78, 293-322.

Battaglene S.C., Seymour J.E. \& Ramofafia C. (2002) Spawning induction of three tropical sea cucumbers, Holothuria scabra, Holothuria fuscogliva and Actinopyga mauritiana. Aquaculture 207, 29-47.

Bruckner A.W., Johnson K.A. \& Field J.D. (2003) Conservation strategies for sea cucumbers: can a CITES Appendix II listing promote sustainable international trade? SPC Beche-de-mer Information Bulletin 18, 24-33.

Chellaram C., Samuel V.D. \& Patterson Edward J.K. (2003) Status of echinoderm fishery in the Gulf of Mannar South east coast of India. Suganthi Devadason Marine Research Institute Research Publication 3, 173-176.

Chen J. (2003) Overview of sea cucumber farming and sea ranching practices in China. SPC Beche-de-mer Information Bulletin 18, 18-23.
Chen C.P. \& Chian C.S. (1990) Short note on the larval development of the sea cucumber Actinopyga echinites (Echinodermata: Holothuroidea). Bulletin of Institute of Zoological Academic Sinica 29, 127-133.

Chia F.S. \& Buchanan J.B. (1969) Larval development of $\mathrm{Cu}$ cumaria elongata (Echinodermata: Holothuridea). Journal of Marine Biological Association of United Kingdom 49, 151-159.

Costelloe J. (1988) Reproductive cycle, development and recruitment of two geographically separated populations of the dendrochirote holothurian Aslia lefevrei. Marine Biology 99, 535-545.

Friedman K. \& Tekanene M. (2005) White teatfish at Kiribati sea cucumber hatchery "Local technicians getting them out again”. SPC Beche-de-mer Information Bulletin $\mathbf{2 1}$, $32-33$.

Gopinathan C.P. (1982) Methods of culturing phytoplankton. In: Manual of Research Method for Fish and Shellfish Nutrition. Central Marine Fisheries Research Institute, Kochi, India. Special Publication 8, 113-118.

Hamel J.F. \& Mercier A. (1996) Early development, settlement, growth and spatial distribution of the sea cucumber Cucumaria frondosa (Echinodermata: Holothuroidea). CanadianJournal of Fisheries and Aquatic Science 53, 253-271.

Hamel J.F., Hidalgo R.Y. \& Mercier A. (2003) Larval development and juvenile growth of the Galapagos sea cucumber Isostichopus fuscus. SPC Beche-de-mer Information Bulletin 18, 3-8.

Imai T., Inaba D., Sato R. \& Hatanaka M. (1950) The artificial rearing of Stichopus japonicus. Tohoku Daigaku Nogakulu Kenkyo Iho 2, 269-277 (in Japanese with English summary).

Ishida M. (1979) Studies on seed production of juvenile sea cucumber Stichopus japonicus. Salbai Gyugyu Gizisu Kalhatsu kenkou 8, 63-75 (in Japanese with English abstract).

Ito S. \& Kitamura H. (1997) Induction of larval metamorphosis in the sea cucumber Stichopus japonicus by periphitic diatoms. Hydrobiologia 358, 281-284.

Ito S. \& Kitamura H. (1998) Technical development in seed production of the Japanese sea cucumber, Stichopus japonicus. SPC Beche-de-mer Information Bulletin 10 , 24-28.

James D.B. (1995) Taxonomic studies on the species of Holothuria (Linnaeus, 1767) from the seas around India part 2. Bombay Natural History Society 19, 190-204.

James D.B. \& Badrudeen M. (1997) Observation on the landings of the sea cucumber Holothuria spinifera at Rameswaram by Chanku madi. Marine Fisheries Information Service Technical and Extension Service 149, 6-8.

James D.B., Rajapandian M.E., Baskar B.K. \& Gopinathan C.P. (1988) Successful induced spawning and rearing of the holothurian Holothuria (Metriatyla) scabra Jaeger at Tuticorin. Marine Fisheries Information Service Technical and Extension Service 87, 30-33.

James D.B., Gandhi A.D., Palaniswamy N. \& Rodrigo J.X. (1994) Hatchery techniques and culture of sea cucumber 
Holothuria scabra. Central Marine Fisheries Research Institute, Kochi, India. Special Publication 57,1-40.

Maruyama Y.K. (1980) Artificial induction of oocyte maturation and development in the sea cucumbers Holothuria leucospilota and Holothuria pardalis. Biological Bulletin 158, 339-348.

McEuen F.S. (1988) Spawning behaviours of north-east Pacific sea cucumbers (Holothuroidea: Echinodermata). Marine Biology 98, 565-585.

McEuen F.S. \& Chia F.S. (1991) Development and metamorphosis of two psolid sea cucumbers, Psolus chitinoides and Psolidium bullatum with a review of reproductive patterns in the family Psolidae (Holothuoidea: Echinodermata). Marine Biology 109, 267-279.
Preston G.L. (1993) Beche-de-mer. In: Nearshore Marine Resources of the South Pacific (ed. by A. Wright \& L. Hills), pp. 119-128. Institute of Pacific studies Suva, Forum Fisheries Agency, International Centre for Ocean Development, Honiara, Canada.

Rutherford J.C. (1973) Reproduction, growth and mortality of the holothurian Cucumaria pseudocurata. Marine Biology 22, 167-176.

Shuxu X. \& Gongchao G. (1981) Experiments on southward transplantation and artificial breeding of the sea cucumber (Stichopus japonicus). Journal of Fisheries China 5, 147-155.

Yingst J.Y. (1978) Patterns of micro and meiofaunal abundance in marine sediments, measured with the adenosine triphosphate assay. Marine Biology 47, 41-54. 